\title{
Assessment of Heavy Metal Concentration and Evaluation of Health Risk of Some Vegetables Cultivated in Loumbila Farmland, Burkina Faso
}

\author{
Tougma Kiswendsida Alain'1, Bambara Telado Luc², Doumounia Ali²*(i), Derra Moumoni³, \\ Inoussa Zongo ${ }^{4}$, Francois Zougmoré5
}

${ }^{1}$ Laboratory of Materials and Environment, Physics Department, University Joseph Ki-Zerbo, Ouagadougou, Burkina Faso ${ }^{2}$ Physics and Chemical Department, Institute of Sciences, Ouagadougou, Burkina Faso

${ }^{3}$ Physics Department, University Norbert Zongo, Koudougou, Burkina Faso

${ }^{4}$ National Center of Scientific Research and Technology, Ouagadougou, Burkina Faso

${ }^{5}$ Physics Department, University Joseph Ki-Zerbo, Ouagadougou, Burkina Faso

Email: *doumouniaali@yahoo.fr

How to cite this paper: Alain, T.K., Luc, B.T., Ali, D., Moumoni, D., Zongo, I. and Zougmoré, F. (2021) Assessment of Heavy Metal Concentration and Evaluation of Health Risk of Some Vegetables Cultivated in Loumbila Farmland, Burkina Faso. Journal of Environmental Protection, 12, 10191032.

https://doi.org/10.4236/jep.2021.1212060

Received: September 2, 2021

Accepted: December 7, 2021

Published: December 10, 2021

Copyright $\odot 2021$ by author(s) and Scientific Research Publishing Inc. This work is licensed under the Creative Commons Attribution International License (CC BY 4.0).

http://creativecommons.org/licenses/by/4.0/ (c) (i) Open Access

\section{Abstract}

Vegetables such as spinach, African eggplant, cabbage, eggplant, okra, chili peppers and tomatoes are found in our everyday foods and are the most important dietary source of nutrient. But, it becomes deleterious to human as well as animals as it accumulates toxic metals in their tissue when grown in contaminated soil. The mostly consumed vegetables like spinach, African eggplant (fruit and leaves), Corchorus olitorius leaf, Amaranthus hybridus leaf, cabbage, eggplant, okra, pepper and tomato were collected from Loumbila market gardening. Heavy metals copper $(\mathrm{Cu})$, nickel $(\mathrm{Ni})$, lead $(\mathrm{Pb})$, chromium $(\mathrm{Cr})$, cadmium $(\mathrm{Cd})$ and zinc $(\mathrm{Zn})$ were measured using atomic absorption spectrophotometer (AAS) model AANALYST 200 from PERKIN ELMER. The results of this study showed that the concentrations of lead (0.49 to $8.59 \mathrm{mg} / \mathrm{kg}$ ) and zinc (20.73 to $71.29 \mathrm{mg} / \mathrm{kg}$ ) in spinach, African eggplant (fruit and leaves), Corchorus olitorius leaf, Amaranthus hybridus leaf, cabbage, eggplant, okra, pepper and tomato exceeded the permissible level of FAO and WHO standard. The daily plant metal intake for Cd (0.001 - 0.015 $\mathrm{mg} / \mathrm{kg}), \mathrm{Pb}(0.041-0.730 \mathrm{mg} / \mathrm{kg})$, and $\mathrm{Cu}(0.703-1.543 \mathrm{mg} / \mathrm{kg})$ is higher than the recommended daily intake of metals but does not exceed the tolerable limit. The calculated values of the health risk indices show high values for $\mathrm{Cd}, \mathrm{Pb}, \mathrm{Zn}, \mathrm{Ni}$ and $\mathrm{Cu}$ while low values are observed for $\mathrm{Cr}$. Except for $\mathrm{Cr}$, the IRS evaluated for all the studied metals were greater than one (IRS $>1$ ). This implies that exposed populations are susceptible to developing diseases linked to the following metals: $\mathrm{Cd}, \mathrm{Pb}, \mathrm{Zn}, \mathrm{Ni}$ and $\mathrm{Cu}$.
\end{abstract}




\section{Keywords}

Heavy Metals, Concentration, Daily Intake, Health Risk Index, Vegetables

\section{Introduction}

Burkina Faso is an agricultural country whose rural sector employs $85 \%$ to $95 \%$ of the total population [1]. Agriculture occupies a preponderant place in the national economy and generates about $42 \%$ of the gross domestic product (GDP) [2]. It appears that market gardening introduced between 1920 and 1930 by the colonial administration represents $8 \%$ to $9 \%$ of agricultural production and $3 \%$ of GDP [3]. The problem of contaminated soil on the perimeters of market gardening is very worrying today in urban cities for emerging countries. Heavy metals such as lead, cadmium, copper, zinc and mercury cannot be biodegraded and therefore persist in the environment for long periods of time. The accumulation of heavy metals in the environment can affect human and animal health [4]. Understanding the origin of heavy metal pollution, the phenomenon of accumulation in soils, and their possible interactions with soil constituents is a priority in many environmental studies. The accumulation of heavy metals in agricultural soils presents an increasing risk of food pollution and a potential risk to human health [5].

The use of waste water can increase the crop productivity, but also increases the contamination of heavy metals $(\mathrm{Pb}, \mathrm{Ni}, \mathrm{Cd}, \mathrm{Cu}, \mathrm{Zn}, \mathrm{Mn}, \mathrm{Cr} . .$.$) in the plants.$ The plants (Amaranthus, Fenugreek and Spinach) heavy metals concentrations depend on the soil concentration [6] [7]. The vegetable from the contaminated soil can accumulate some high concentration of heavy metal and cause some serious risk to human health [8]. As an example, [9] John et al., show that the vegetable and the soil from Kaduna city are polluted by $\mathrm{Pb}, \mathrm{Cd}$ and $\mathrm{Cr}$ [9]. The concentration of $\mathrm{Pb}$ in cabbage, (10.51), lettuce (10.19), green pepper (9.44), hot pepper (7.61) and ayoyo (9.05) from some parts of Accra were higher than the $\mathrm{FAO} / \mathrm{WHO}$ maximum recommended limit of $0.30 \mathrm{mg} / \mathrm{kg}$ for $\mathrm{Pb}[10]$.

The concentration of cadmium $(\mathrm{Cd})$, lead $(\mathrm{Pb})$ and chromium $(\mathrm{Cr})$ in vegetable species (Telferia occidentalis, Talinum triangulare, Ocimum gratissimum, Celosia argentea, and Amaranthus viridis) cultivated in Lagos farmlands and floodplains, were above standard limit [11]. Heavy metals in plants can accumulate in the human body and cause diseases such as Colon, stomach, liver, lung, bladder and kidney cancers [12] [13] [14].

Trace metal elements contained in wastewater are toxic and non-biodegradable substances that accumulate in the soil and, depending on biogeochemical conditions, can lead to soil degradation [15]. Studies show that even treated wastewater also contains heavy metals that can contaminate crops when used for irrigation [16].

Metal elements such as $\mathrm{Fe}, \mathrm{Zn}, \mathrm{Mo}, \mathrm{Cu}, \mathrm{Co}$ and $\mathrm{Cr}$ are known to be essential 
elements in the living organism. However, a high concentration can be potentially toxic [17].

Pollution can be due on the one hand to the use of wastewater for irrigation and on the other hand to the proximity of the production sites of major urban traffic axes and industries that emit heavy metals [18]. The accumulation of heavy metals in soil can be due to the irrigation water and thereafter contaminate the vegetable and fruit. Heavy metal concentrations in vegetable are different to those of the fruits that reveal the difference between their capacities of accumulation [19].

The contamination of soils, plants and water by heavy metals constitutes an important public health issue which requires more information on the various sources of pollution and on the rate of contamination. Preliminary studies on heavy metal pollution in the market gardening areas of Ouagadougou and Loumbila have revealed a deterioration in soil quality [20]. Concentration values of certain metals ( $\mathrm{Cr}, \mathrm{Mn}, \mathrm{Ni}$ and $\mathrm{Hg}$ ) in irrigation water were found to be above standards. A high concentration of chromium was observed in tomato [21]. The alert resulting from this study on the potential risk of pollution of agricultural soils and transfer of pollutants into the food chain justifies the need to continue studies on the market gardening areas of Ouagadougou and Loumbila on other plants.

Based on the work carried out on heavy metals in plants in West Africa (Ghana, Nigeria, etc.) in general and in Burkina Faso in particular, this study focused on copper $(\mathrm{Cu})$, chromium $(\mathrm{Cr})$, zinc $(\mathrm{Zn})$, lead $(\mathrm{Pb})$, nickel $(\mathrm{Ni})$, and cadmium (Cd) in the most consumed plants [10] [11] [20].

The objective of this study is to estimate the concentration of heavy metals $(\mathrm{Cu}, \mathrm{Cr}, \mathrm{Zn}, \mathrm{Pb}, \mathrm{Ni}$, and $\mathrm{Cd})$ in market gardening products at the Loumbila market gardening sites and evaluate health risk.

\section{Material and Method}

\subsection{Study Area}

In this study, the vegetables samples were collected in different agricultural areas at Loumbila market garden. Distance of 18 kilometers from Ouagadougou capital city of Burkina, Loumbila market garden is expanding around the dam. The dam is located at a longitude of $01^{\circ} 24^{\prime} 07.4$ West and a latitude of $12^{\circ} 29^{\prime} 35.8$ North with the water capacity of 42.2 million cubic meter. It is used by market gardeners to irrigate the plants [22].

Loumbila's market gardening areas have a much diversified production of vegetables, namely onion, tomato, okra, zucchini, African eggplant, eggplant, pepper, bell pepper, lettuce, cabbage, carrot, green bean, and potato. Market garden products from Loumbila can be found in most markets in the city of Ouagadougou or exported to neighboring countries. These reasons led to the choice of the Loumbila market gardening areas to carry out this study, by choosing the most consumed vegetables in the city of Ouagadougou. 


\subsection{Sample Collection}

During this study, a vegetables samples collection campaign was carried out in the Loumbila market gardening area located downstream from the dam. The following materials were used for sample collection:

A pickaxe to dig up the chosen plant species;

> A ceramic knife to separate leaves and fruits lengthwise to ensure consistency in analyzes. The ceramic knife prevents any external contamination;

The plastic seals to wash the samples of the plants taken;

$>$ Distilled water for rinsing the leaves and fruits;

A cooler containing ice for storing samples.

Sampling was carried out at regular intervals and over the entire plot for each type of sample. The different plants were sampled by separating the different plant tissues (roots, leaves, stems and fruits) of each plant using a ceramic knife to avoid contamination. To measure an average concentration, at the plot level, the samples were mixed by family and constitute an aliquot. Plant samples for analysis of heavy metal were placed in plastic bags. These samples were then stored at $-20^{\circ} \mathrm{C}$ in the BUMIGEB Analysis Laboratory. African eggplant, cabbage, okra, eggplant, corchorus olitorius leaf, amaranthus hybridus leaf, lettuce, spinach, tomato and chili were collected during the campaign.

\subsection{Sample Preparation}

The vegetables were washed up with tap water thoroughly to remove the attached dust particles, soil, unicellular algae, etc. Then they were washed with distilled water and finally with deionized water. The washed vegetables were dried at room temperature to remove surface water. The vegetables were immediately kept in desiccators to avoid further evaporation of moisture from the materials. After that the vegetables were chopped into small pieces and were oven dried. Then the vegetables were crushed into fine powder using a porcelain mortar and pestle. The resulting powder was kept in air tight polythene packet at room temperature before being taken to the laboratory for digestion and metals analysis.

\subsection{Digestion and Metal Analysis}

The vegetable sample $(1 \mathrm{~g})$ were weighed into a $100 \mathrm{ml}$ volumetric flask and concentrated acids of $10.0 \mathrm{~mL}$ of concentrated sulfuric acid were added to each sample. The samples obtained after adding concentrated acid were gently on a hot plate, stirring occasionally until the powder completely dissolved in the solution (about 10 to 15 minutes). Then $10 \mathrm{ml}$ of distilled water was added and the whole was heated gently for a few minutes (5 to 10 mins). Finally, the solution was left to stand for it to settle well and the filtrate was taken for analysis.

A model AANALYST 200 flame atomic absorption spectrometer from PERKIN ELMER was used for copper $(\mathrm{Cu})$, chromium $(\mathrm{Cr})$, zinc $(\mathrm{Zn})$, lead $(\mathrm{Pb})$, nickel $(\mathrm{Ni})$, and cadmium $(\mathrm{Cd})$ analysis. 
The final concentration of each metal in the plant was calculated using the following formula:

$$
\text { Cfinal }(\mathrm{mg} / \mathrm{kg})=\frac{\text { Cmetal } * \text { dilution factor } * \text { nominalvolume }}{\text { sample weight }(\mathrm{g})}
$$

For the plant: The nominal volume is $20 \mathrm{ml}$ and the sample weight is $0.5 \mathrm{~g}$ [23].

\subsection{Estimation of Health Risk}

\subsubsection{Daily Intake}

The potential health risk linked to the ingestion of heavy metals through the consumption of vegetables is assessed on the basis of the daily intake of the metal (DIM) and the health risk index (HRI).

The daily intake of each metal in this study is calculated from the formula below:

$$
\mathrm{DIM}=\frac{\mathrm{C}_{\text {metal }} \times \mathrm{C}_{\text {factor }} \times \mathrm{C}_{\text {veg.cons }}}{\mathrm{B}_{\text {average weight }}}
$$

where, $\mathrm{C}_{\text {metal }}$ is the concentration of heavy metals in vegetables $(\mathrm{mg} / \mathrm{kg}), \mathrm{C}_{\text {factor }}$ is the conversion factor, $\mathrm{C}_{\text {veg.cons }}$ is the daily intake of vegetables and $\mathrm{B}_{\text {average weight }}$ is the average body weight for the adult consumer.

The conversion factor of 0.085 is used to convert the weight of fresh vegetable to weight of dry substance, the daily amount of vegetables for an adult is assumed to be $65 \mathrm{~g}$, while the average adult consumer weight of the vegetable used is $65 \mathrm{~kg}$ in this study [24] (Ramteke et al., 2016; [11] Adedokun et al., 2017; [25] Alipour et al., 2018; [26] Hailu et al., 2020; [27] Miranzadeh et al., 2020).

\subsubsection{Health Risk Index}

The health risk index (HRI) was calculated using the formula below:

$$
\text { HRI }=\frac{\text { DIM }}{\text { ORI }}
$$

where DIM is the daily intake of the metal and ORI is the oral reference intake.

ORI values for $\mathrm{Pb}, \mathrm{Cd}, \mathrm{Cu}, \mathrm{Zn}, \mathrm{Cr}$ and $\mathrm{Ni}$ are $0.0035 \mathrm{mg} / \mathrm{kg} / \mathrm{day}, 0.001$ $\mathrm{mg} / \mathrm{kg} /$ day, $0.040 \mathrm{mg} / \mathrm{kg} /$ day, $0.300 \mathrm{mg} / \mathrm{kg} /$ day, $1.5 \mathrm{mg} / \mathrm{kg} / \mathrm{day}$ and $0.020 \mathrm{mg} /$ kg/day, respectively [24] (Ramteke et al., 2016; [11] Adedokun AH, 2017).

The HRI $<1$ means that the exposed population is safe from the health risks of metals while the HRI $>1$ means the population is exposed to a high health risk from heavy metals [28] (Khan et al., 2008).

The results obtained from the different assays of the plant (leaf) and fruit samples are presented and discussed in point III.

\section{Results and Discussions}

In this study, the evaluation of the concentrations of heavy metals in certain vegetables from Loumbila market gardening were evaluated. The heavy metals analyzed in vegetables samples were copper $(\mathrm{Cu})$, chromium $(\mathrm{Cr})$, zinc $(\mathrm{Zn})$, 
lead $(\mathrm{Pb})$, nickel $(\mathrm{Ni})$, and cadmium $(\mathrm{Cd})$. The sampling concerned nine (9) vegetables from the Loumbila market gardening site.

The plants concerned during this campaign were spinach (leaf), african eggplant (leaf and fruit), Corchorus olitorius (leaf), hybrid amaranth (leaf), cabbage, eggplant (fruit), okra (fruit), pepper (fruit) and tomato (fruit). These plant samples were analyzed with a PERKIN ELMER type atomic absorption spectrometer.

\subsection{Heavy Metals Concentration in Plants}

The averages values of heavy metal concentrations $(\mathrm{mg} / \mathrm{kg})$ in spinach, african eggplant, Corchorus olitorius leaf, Amaranthus hybridus leaf, cabbage, eggplant, okra, pepper and tomato are given in Table 1.

Spinach leaf: The studied heavy metals concentrations in spinach leaf samples vary between 0.12 and $59.03 \mathrm{mg} / \mathrm{kg}$. Zinc concentration was highest in spinach leaf samples and cadmium had the lowest concentration.

African eggplant: Samples of African eggplant fruit and leaf were collected and analyzed. The heavy metals concentrations vary between 0.06 and 34.48 $\mathrm{mg} / \mathrm{kg}$ for the leaves and between 0 and $20.73 \mathrm{mg} / \mathrm{kg}$ for the fruits. Zinc concentration was highest in African eggplant samples and chromium had the lowest concentration. African eggplant leaves accumulate more copper, nickel, zinc, cadmium and chromium than fruits. On the other hand, lead was more present in fruits.

Corchorus olitorius leaf: The concentrations of heavy metals studied in the corchorus olitorius leaf samples vary between 0.03 and $29.98 \mathrm{mg} / \mathrm{kg}$. Zinc concentration is highest in the corchorus olitorius leaf samples and cadmium had the lowest concentration.

Table 1. Heavy metals concentration in plant samples.

\begin{tabular}{ccccccc}
\hline \multirow{2}{*}{ Samples } & \multicolumn{6}{c}{ Heavy Metal Concentration in $\mathrm{mg} / \mathrm{kg}$} \\
\cline { 2 - 7 } & $\mathrm{Cu}$ & $\mathrm{Ni}$ & $\mathrm{Zn}$ & $\mathrm{Cd}$ & $\mathrm{Cr}$ & $\mathrm{Pb}$ \\
\hline Spinach leaf & 10.99 & 1.15 & 59.03 & 0.12 & 0.91 & 2.47 \\
African Eggplant leaf & 18.15 & 1.79 & 34.48 & 0.08 & 0.06 & 0.49 \\
Corchorus olitorius leaf & 8.27 & 1.01 & 29.98 & 0.03 & 1.05 & 4.1 \\
Amaranthus hybridus leaf & 9.4 & 1.57 & 41.4 & 0.1 & 0.97 & 3.61 \\
Cabbage leaf & 5 & 1.78 & 51.7 & 0.06 & 1.57 & 3.09 \\
Eggplant & 12.21 & 0.73 & 23.13 & 0.03 & 0.65 & 5.11 \\
African Eggplant & 11.39 & 1.13 & 20.73 & 0.04 & 0 & 2.14 \\
Okra & 11.27 & 1.92 & 46.68 & 0.01 & 1.05 & 8.59 \\
Pepper & 9.8 & 1.26 & 22.11 & 0.06 & 2.53 & 4.29 \\
Tomato & 15.11 & 2.26 & 71.29 & 0.18 & 1.42 & 5.97 \\
Limit values in plants & 40 & $70-80$ & 20 & 0.2 & 2.3 & 0.3 \\
\hline
\end{tabular}


Amaranthus hybridus leaf: Cadmium has the lowest concentration in Amaranthus hybridus leaves with a value of $0.1 \mathrm{mg} / \mathrm{kg}$, while zinc had a high concentration of $41.4 \mathrm{mg} / \mathrm{kg}$.

Cabbage leaf: In cabbage leaves, cadmium has the lowest concentration with a value of $0.06 \mathrm{mg} / \mathrm{kg}$ while zinc has the highest concentration: $51.7 \mathrm{mg} / \mathrm{kg}$.

Eggplant fruit: the concentrations of the metals studied in eggplant vary between 0.03 and $23.13 \mathrm{mg} / \mathrm{kg}$. The heavy metal with the highest concentration was zinc.

Okra fruit: Cadmium concentration was lowest in cabbage with a value of 0.01 $\mathrm{mg} / \mathrm{kg}$ and the metal zinc is the most accumulated with a concentration of 46.68 $\mathrm{mg} / \mathrm{kg}$.

Pepper fruit: The concentrations of heavy metals studied in the peppers samples vary between 0.06 and $22.11 \mathrm{mg} / \mathrm{kg}$. Zinc concentration was highest in samples and cadmium concentration was lowest.

Tomato fruit: The concentrations of the metals studied in tomato vary between 0.18 and $71.29 \mathrm{mg} / \mathrm{kg}$. The metal with the highest concentration was zinc and cadmium had the lowest concentration.

The $\mathrm{Cu}$ level of vegetables obtained from Loumbila market garden ranged between $5.00 \mathrm{mg} / \mathrm{kg}$ in cabbage and $18.15 \mathrm{mg} / \mathrm{kg}$ in African Eggplant leaf. The $\mathrm{Cu}$ levels in the vegetables presented in this study were lower than WHO/FAO suggested safe limits of $40 \mathrm{mg} / \mathrm{kg}$. Copper is an essential micronutrient which functions as a biocatalyst required for body pigmentation in addition to iron, maintain a healthy central nervous system, prevents anaemia and interrelated with the functions of zinc and iron in the body [11] (Adedokun et al., 2017).

Nickel is essential for growth and reproduction in livestock and man, but could be carcinogenic in high amount in the body. In this study, the concentrations of nickel in the vegetables from the Loumbila market garden ranged between $0.73 \mathrm{mg} / \mathrm{kg}$ in eggplant and $2.26 \mathrm{mg} / \mathrm{kg}$ in tomato.

$\mathrm{Ni}$ content in vegetables was found to be lower than the estimated maximum guideline set by United State Food and Drug Administration of $70-80 \mathrm{mg} / \mathrm{g}$. These variations of $\mathrm{Ni}$ concentration in various vegetables might be due to the pollutants in soil, air, water, factory wastages, sewerages etc. Nickel is reported to be a common cause of allergic contact dermatitis [11] (Adedokun et al., 2017).

In human body, $\mathrm{Zn}$ is essential for normal growth, mental ability, immune system, reproduction and healthy function of the heart [11] (Adedokun et al., 2017). The level of $\mathrm{Zn}$ in the vegetables from Loumbila market garden ranged between $20.73 \mathrm{mg} / \mathrm{kg}$ and $71.29 \mathrm{mg} / \mathrm{kg}$ with the highest recorded in tomato and the least in African Eggplant. All concentrations of $\mathrm{Zn}$ obtained in this study, were higher than the permissible levels by $\mathrm{FAO} / \mathrm{WHO}$ in vegetables of $20 \mathrm{mg} / \mathrm{kg}$. In the study done by Bambara et al. (2015) [21], the concentration of $\mathrm{Zn}$ in the vegetables from Loumbila market garden ranged between $0.26 \mathrm{mg} / \mathrm{kg}$ and 4.52 $\mathrm{mg} / \mathrm{kg}$ with the highest recorded in tomato. This study and the study done by Bambara et al. (2015) [21] shown that Tomato absorbed more the zinc. Con- 
sumption of vegetables from Loumbila market garden could cause nausea, vomiting, loss of appetite, abdominal cramps, diarrhea, headaches and inhibition of copper absorption which sometimes produce copper deficiency and associated anemia [11] (Adedokun et al., 2017).

The concentrations of $\mathrm{Cd}$ in the vegetables from the Loumbila market garden ranged between $0.01 \mathrm{mg} / \mathrm{kg}$ in okra and $0.18 \mathrm{mg} / \mathrm{kg}$ in tomato. Differing values have been previously reported in leafy vegetables which include $0.366 \mathrm{mg} / \mathrm{kg}$ from Baskuy and $0.219 \mathrm{mg} / \mathrm{kg}$ from Boulbi by Derra et al. (2018) [29] for lettuce. In this study, the concentration of $\mathrm{Cd}$ was lower than in these previous studies and also above the permissible levels by FAO/WHO in vegetable $(0.2 \mathrm{mg} / \mathrm{kg})$.

Consumption of food grown in contaminated areas is primary source of Cadmium (Cd) in human body [11] (Adedokun et al., 2017). Cadmium accumulates primarily in the kidneys and has a long biological half-life in humans of 10 - 35 years. The critical level of cadmium in the kidneys capable of causing renal failure in adults is $200 \mathrm{mg} / \mathrm{kg}$; this is possible if the daily food intake reaches $175 \mathrm{mg}$ per person for 50 years [11] (Adedokun et al., 2017).

The concentrations of $\mathrm{Cr}$ in the vegetables from Loumbila market garden ranged between $0.0 \mathrm{mg} / \mathrm{kg}$ in African Eggplant to $2.53 \mathrm{mg} / \mathrm{kg}$ in pepper. Chromium levels in pepper only was higher than the safe limits $(2.3 \mathrm{mg} / \mathrm{kg})$ and also made similar observation in a study of tomato obtained in Loumbila market garden [21] (Bambara et al., 2015). These high concentrations of $\mathrm{Cr}$ might be accumulated in the vegetables due to the contamination of soil, wastewater or fertilizer [6] (Jayadev et al., 2013; [7] Arti et al., 2013; [18] Tankari et al., 2013). $\mathrm{Cr}$ is a trace element necessary for carbohydrate, fat and cholesterol metabolism and important for many hormones and enzyme activity in a certain concentration (up to $200 \mathrm{mg} /$ day) but chronic exposure to Cr may damage liver and kidney [11] (Adedokun et al., 2017).

The highest $\mathrm{Pb}$ concentration in vegetables obtained from Loumbila market garden was recorded in Okra $(8.59 \mathrm{mg} / \mathrm{kg})$ and the least in African Eggplant leaf $(0.49 \mathrm{mg} / \mathrm{kg})$. All concentrations of $\mathrm{Pb}$ obtained in this study, were higher than the permissible levels by $\mathrm{FAO} / \mathrm{WHO}$ in vegetables of $0.3 \mathrm{mg} / \mathrm{kg}$. The values have been previously reported in leafy vegetables which include $8.194 \mathrm{mg} / \mathrm{kg}$ from Baskuy and $5.307 \mathrm{mg} / \mathrm{kg}$ from Boulbi by [29] Derra et al. (2018) for lettuce. The high levels of lead in all vegetables samples may probably be attributed to pollutants in irrigation water, farm soil, fertilizer or due to pollution from the highways traffic and industrial sites located around the sampled locations [6] (Jayadev et al., 2013; [7]Arti et al., 2013; [18] Tankari et al., 2013). Pb is highly toxic heavy element and its intake via vegetable consumption can cause effect on liver, kidney, vascular and immune system [11] (Adedokun et al., 2017).

This study showed that the plants in the study area, have lead and zinc concentrations above the FAO recommended limit concentration in plants. The lead concentration in okra fruit is of great concern as it is about 29 times higher than the recommended limit in plants. It is also noted that only chilli fruit has a 
chromium concentration above the recommended limit. This could have consequences on the human health of the populations that consume these products.

In all the plant samples studied, zinc has the highest concentration, which of tomato is the highest with a value of $71.29 \mathrm{mg} / \mathrm{kg}$. This study shows that zinc is the most accumulated metal in plants among the metals studied at our site in Loumbila. The concentration of zinc in tomato is about four times higher than the FAO recommended limit value in plants. This study also shows that cadmium is the least present metal in the samples analyzed.

\subsection{Comparison of Heavy Metal Concentrations in Leaves and Fruits}

Table 2 and Figure 1 show the average values, the standard deviations, the maximum and minimum values of the heavy metals concentrations in the studied leaves and fruits.

Table 2. Comparison of heavy metal concentrations in leaves and fruits.

\begin{tabular}{cccccccc}
\hline \multirow{4}{*}{ Leaves } & Vegetable & $\mathrm{Cu}$ & $\mathrm{Ni}$ & $\mathrm{Zn}$ & $\mathrm{Cd}$ & $\mathrm{Cr}$ & $\mathrm{Pb}$ \\
\hline \multirow{4}{*}{ Average } & 10.36 & 1.46 & 43.32 & 0.08 & 0.91 & 2.75 \\
& Standard deviation & 3.37 & 0.3 & 9.64 & 0.03 & 0.34 & 1.02 \\
& Maximum & 18.15 & 1.79 & 59.03 & 0.12 & 1.57 & 4.1 \\
& Minimum & 5 & 1.01 & 29.98 & 0.03 & 0.06 & 0.49 \\
\hline \multirow{3}{*}{ Fruits } & Average & 11.96 & 1.46 & 36.79 & 0.06 & 1.13 & 5.22 \\
& Standard deviation & 1.36 & 0.5 & 17.76 & 0.05 & 0.68 & 1.65 \\
& Maximum & 15.11 & 2.26 & 71.29 & 0.18 & 2.53 & 8.59 \\
& Minimum & 9.8 & 0.73 & 20.73 & 0.01 & 0 & 2.14 \\
\hline
\end{tabular}

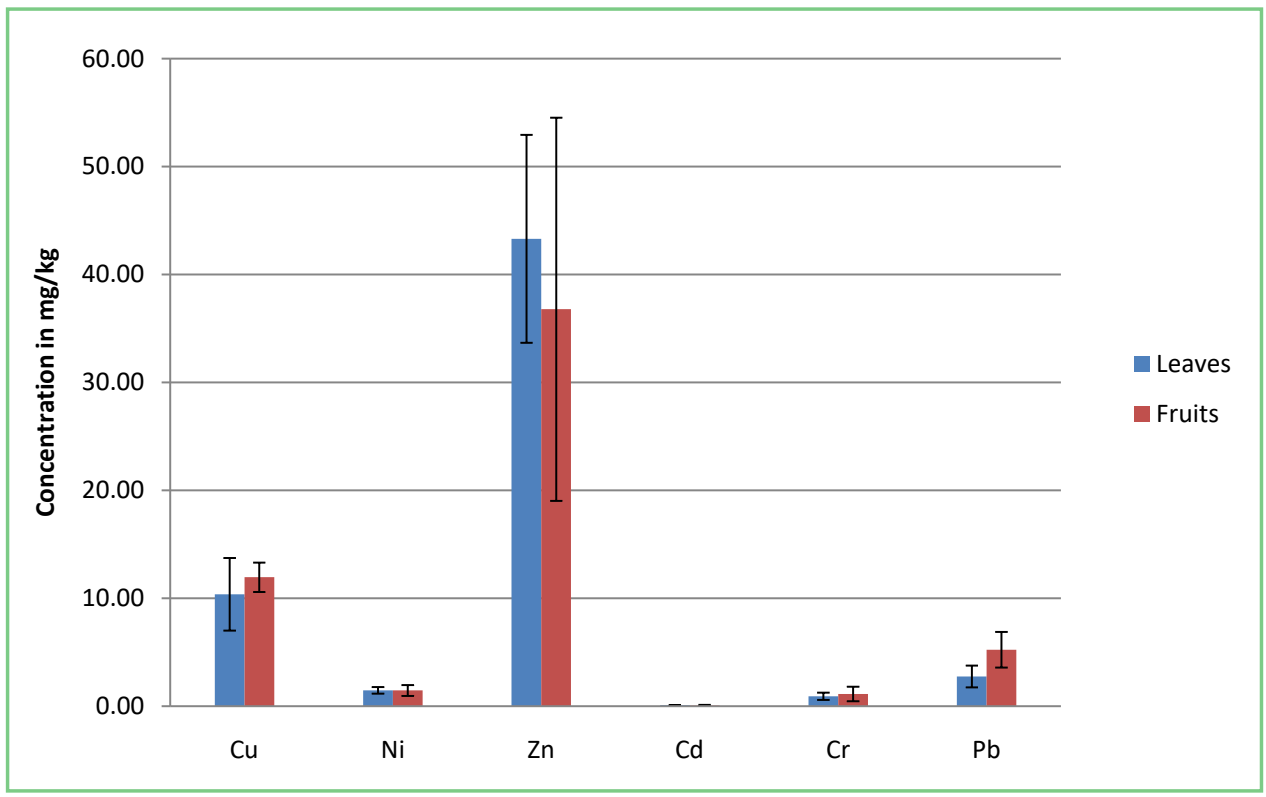

Figure 1. Average concentration in the studied leaves and fruits. 
The average concentrations of copper, chromium and lead are higher in the fruits than in the leaves, whereas that of zinc is higher in the leaves than in the fruits (Figure 1). So this study shows a strong accumulation of zinc in the leaves and strong accumulation of copper, nickel, chromium and lead in the fruits.

\subsection{Health Risk}

The assessment of health risk due to the presence of heavy metals in the plants consumed was done by calculating the daily intake of heavy metals and the health risk index.

\subsubsection{Daily Intake of Heavy Metals}

The results of the calculation of the daily dose of heavy metals are presented in Table 3 together with the recommended daily intake and the tolerable limits of the daily intake established by the Institute of Medicine in the United States of America for aged populations between 19 and 70 years old [11] (Adedokun et al., 2017).

The degree of heavy metal toxicity in humans depends on the daily intake. The daily plant metal intake for $\mathrm{Cd}(0.001-0.015 \mathrm{mg} / \mathrm{kg}), \mathrm{Pb}(0.041-0.730$ $\mathrm{mg} / \mathrm{kg})$, and $\mathrm{Cu}(0.703-1.543 \mathrm{mg} / \mathrm{kg})$ is higher than the recommended daily intake of metals but does not exceed the tolerable limit. The daily intake of lead exceeds the tolerable limit for plants such as, Corchorus olitorius (leaf), Amaranthus hybridus (leaf), cabbage, eggplant (fruit), okra (fruit), pepper (fruit)) and tomato (fruit). However, the calculated daily intake for $\mathrm{Cr}(0.000-0.215$ $\mathrm{mg} / \mathrm{kg}$ ) was lower than the recommended reference dose of $1.5 \mathrm{mg} / \mathrm{kg}$ [30] (USEPA, 2010).

\subsubsection{Health Risk Index (HRI)}

The values of the health risk index calculated for $\mathrm{Cd}, \mathrm{Pb}, \mathrm{Zn}, \mathrm{Cr}, \mathrm{Ni}$, and $\mathrm{Cu}$ are presented in Table 4.

Table 3. Daily intake of heavy metals in $\mathrm{mg} /$ person/day.

\begin{tabular}{ccccccc}
\hline Vegetables & $\mathrm{Cu}$ & $\mathrm{Ni}$ & $\mathrm{Zn}$ & $\mathrm{Cd}$ & $\mathrm{Cr}$ & $\mathrm{Pb}$ \\
\hline Spinach leaf & 0.934 & 0.098 & 5.018 & 0.01 & 0.077 & 0.21 \\
African Eggplant leaf & 1.543 & 0.152 & 2.931 & 0.007 & 0.005 & 0.042 \\
Corchorus olitorius leaf & 0.703 & 0.086 & 2.548 & 0.003 & 0.089 & 0.349 \\
Amaranthus hybridus leaf & 0.799 & 0.133 & 3.519 & 0.009 & 0.082 & 0.307 \\
Cabbage leaf & 0.425 & 0.151 & 4.395 & 0.005 & 0.133 & 0.263 \\
Eggplant & 1.038 & 0.062 & 1.966 & 0.003 & 0.055 & 0.434 \\
African Eggplant & 0.968 & 0.096 & 1.762 & 0.003 & 0 & 0.182 \\
Okra & 0.958 & 0.163 & 3.968 & 0.001 & 0.089 & 0.73 \\
Pepper & 0.833 & 0.107 & 1.879 & 0.005 & 0.215 & 0.365 \\
Tomato & 1.284 & 0.192 & 6.06 & 0.015 & 0.121 & 0.507 \\
Recommended daily intake & 0.9 & 0.5 & 8 & 0 & - & 0 \\
Upper tolerable daily intake & 10 & 1 & 40 & 0.064 & - & 0.24 \\
\hline
\end{tabular}


Table 4. Health risk index (HRI).

\begin{tabular}{ccccccc}
\hline Vegetables & $\mathrm{Cu}$ & $\mathrm{Ni}$ & $\mathrm{Zn}$ & $\mathrm{Cd}$ & $\mathrm{Cr}$ & $\mathrm{Pb}$ \\
\hline Spinach leaf & 23.35 & 4.89 & 16.73 & 10.2 & 0.05 & 59.99 \\
African Eggplant leaf & 38.57 & 7.61 & 9.77 & 6.8 & 0 & 11.9 \\
Corchorus olitorius leaf & 17.57 & 4.29 & 8.49 & 2.55 & 0.06 & 99.57 \\
Amaranthus hybridus leaf & 19.98 & 6.67 & 11.73 & 8.5 & 0.05 & 87.67 \\
Cabbage leaf & 10.63 & 7.57 & 14.65 & 5.1 & 0.09 & 75.04 \\
Eggplant & 25.95 & 3.1 & 6.55 & 2.55 & 0.04 & 124.1 \\
African Eggplant & 24.2 & 4.8 & 5.87 & 3.4 & 0 & 51.97 \\
Okra & 23.95 & 8.16 & 13.23 & 0.85 & 0.06 & 208.61 \\
Pepper & 20.83 & 5.36 & 6.26 & 5.1 & 0.14 & 104.19 \\
Tomato & 32.11 & 9.61 & 20.2 & 15.3 & 0.08 & 144.99 \\
\hline
\end{tabular}

Generally, the HRI $<1$ means that the exposed population is safe from the health risks of metals while the HRI $>1$ means the population is exposed to a high health risk from heavy metals [28] (Khan et al., 2008).

Except for Cr, the HRI assessed for all studied metals was greater than one. This implies that $\mathrm{Cd}, \mathrm{Pb}, \mathrm{Zn}, \mathrm{Ni}$ and $\mathrm{Cu}$ could pose severe health risk to humans who consume these plants.

The health risk indices for all species plant are as follows: $\mathrm{Cu}$ (10.63 to 38.57), $\mathrm{Ni}$ (0.00 to 9.61), Zn (5.87 to 20.20), Cd (0.85 to 15.30$), \mathrm{Cr}$ (0.00 to 0.14 ) and $\mathrm{Pb}$ (11.66 to 208.61). The result of the health risk index shows high values for $\mathrm{Cd}$, $\mathrm{Pb}, \mathrm{Zn}, \mathrm{Ni}$ and $\mathrm{Cu}$ while low values was observed for $\mathrm{Cr}$.

The results of analysis show that all leaf and fruit samples had very high concentrations of zinc and lead.

At the fruit level, it was observed that only the pepper had the chromium concentration which exceeds the regulatory limit while the leaves of African eggplant had the lowest value. The concentrations of cadmium, copper and nickel do not reach recommended limit.

The toxicity of some samples has been proven. Base on than, the daily intake per person and for each heavy metal were evaluated. The results show that the daily intake of cadmium, copper and lead exceed the recommended value but do not present any danger because these values were below the tolerable exposure limits. On the other hand, the toxicity of lead is confirmed in all the samples taken because its value exceeds the authorized tolerable limit [30] (USEPA, 2010). As the daily intake of certain metals exceeded the authorized tolerable limit, it was important to assess the health risk generated following ingestion of the samples by the population. In principle, if the HRI $<1$, there is no risk of exposure and if HRI $>1$ means that the population is exposed to a high health risk from heavy metals [28] (Khan et al., 2008). As for the HRI calculations, the results show that cadmium, lead, copper, zinc and nickel had an HRI $>1$ and therefore present dangers to the health of populations who could consume these 
market garden products.

\section{Conclusions}

The main objective of this paper was to estimate the concentration of heavy metals in vegetable from Loumbila market garden and evaluate the health risk.

This study indicated that concentrations of Cadmium, Chromium, Copper and Nickel in the vegetables from Loumbila market garden were below the safe limits of $0.2 \mathrm{mg} / \mathrm{kg}, 2.3 \mathrm{mg} / \mathrm{kg}, 40 \mathrm{mg} / \mathrm{kg}$, and $70-80 \mathrm{mg} / \mathrm{kg}$ respectively, set by the WHO/FAO and USFDA while and concentrations of lead and zinc were above. The daily plant metal intake for $\mathrm{Cd}(0.001-0.015 \mathrm{mg} / \mathrm{kg}), \mathrm{Pb}(0.041-$ $0.730 \mathrm{mg} / \mathrm{kg})$, and $\mathrm{Cu}(0.703-1.543 \mathrm{mg} / \mathrm{kg})$ is higher than the recommended daily intake of metals but does not exceed the tolerable limit.

The HRI result showed high values for $\mathrm{Cd}, \mathrm{Pb}, \mathrm{Zn}, \mathrm{Ni}$ and $\mathrm{Cu}$. This implies that $\mathrm{Cd}, \mathrm{Pb}, \mathrm{Zn}, \mathrm{Ni}$ and $\mathrm{Cu}$ could pose severe health risk to people consuming spinach, African eggplant, cabbage, eggplant, okra, chili peppers and tomatoes from Loumbila market garden.

\section{Acknowledgements}

Laboratory of Materials and Environment of University Joseph KI-ZERBO is appreciated for providing the financial resources to conduct this study.

\section{Conflicts of Interest}

The authors declare no conflicts of interest regarding the publication of this paper.

\section{References}

[1] Compaoré, D. (2008) Diagnostic de l'agriculture urbaine à Ouagadougou: Mise en place d'un système d'information pour la planification.

[2] MAHRH/DSA/Enquête maraichère (2007) Campagne 2001-2002 et RGA 2006-2010.

[3] Sawadogo, M (2012) Utilisation des pesticides dans les cultures maraîchères en zone urbain et périurbain de Ouagadougou: Etude des risques toxicologiques.

[4] Dung, H.T.M. (2012) Impacts des métaux lourds sur l'interaction plante/ver de terre/microflore tellurique. Thèse, Présentée et soutenue publiquement le 22/12/2012 pour l'obtention du grade de Docteur de L'UNIVERSITE PARIS EST, 169 p.

[5] Salano, E.M. (2013) Assessment of Heavy Metal Pollution in Soils and Water of Samburu County, Kenya. Thesis, Kenyatta University, Nairobi.

[6] Puttaih, J.E.T. (2013) Assessment of Heavy Metals Uptake in Leafy Vegetables Grown on Long Term Wastewater Irrigated Soil across Vrishabhavathi River, Bangalore, Karnataka. IOSR Journal of Environmental Science, Toxicology and Food Technology, 7, 52-55. https://www.iosrjournals.org/iosr-jestft/papers/vol7-issue6/I0765255.pdf

[7] Yadav, A., Yadav, P.K. and Shukla, D.N. (2013) Investigation of Heavy Metal Status in Soil and Vegetables Grown in Urban Area of Allahabad, Uttar Pradesh, India. International Journal of Scientific and Research Publications, 3, 1-7.

[8] Naser, H.M., Sultana, S., Mahmud, N.U., Gomes, R. and Noor, S. (2011) Heavy 
Metal Levels in Vegetables with Growth Stage and Plant Species Variations. Bangladesh Journal of Agricultural Research, 36, 563-574. https://doi.org/10.3329/bjar.v36i4.11743

[9] Jacob, J.O. and Kakulu, S.E. (2012) Assessment of Heavy Metal Bioaccumulation in Spinach, Jute Mallow and Tomato in Farms within Kaduna Metropolis, Nigeria. American Journal of Chemistry, 2, 13-16.

https://doi.org/10.5923/j.chemistry.20120201.04

http://journal.sapub.org/chemistry

[10] Lente, I., Ofosu-Anim, J., Brimah, A.K. and Atiemo, S. (2014) Heavy Metal Pollution of Vegetable Crops Irrigated with Wastewater in Accra, Ghana. West African Journal of Applied Ecology, 22, 41-58.

[11] Adedokun, A.H., Njoku, K.L., Akinola, M.O., Adesuyi, A.A. and Jolaoso, A.O. (2017) Heavy Metal Content and the Potential Health Risk Assessment of Some Leafy Vegetables Cultivated in Some Flood Plains and Farmlands in Lagos, Nigeria. FUNAI Journal of Science \& Technology, 3, 30-47.

[12] Huss, J. (2011) Les risques sanitaires des métaux lourds et d'autres métaux. Rapport 1 de la Commission des questions sociales, de la santé et de la famille, de l'Assemblée parlementaire de l'union européen, Doc. 12613.

[13] Said, B.M. (2011) Etude des impacts environnementaux des débris de démolition de la région de Boumerdes. Thèse soutenue le pour l'obtention du grade de docteur de l'Université M'Hamed Bougara-Boumerdes, Année universitaire: 2010/2011, p 146.

[14] Aloueimine, S.O. (2006) Méthodologie de caractérisation des déchets ménagers à Nouakchott (Mauritanie): Contribution à la gestion des Déchets et outils d'aide à la décision. Thèse Présentée et soutenue publiquement le 13 Avril 2006 pour l'obtention du grade de Docteur de l'Université de Limoges, p 195.

[15] Matech, F., Zaakour, F., Moustarhfer, K. and Chemsi, Z. (2014) Concentrations en éléments traces métalliques dans les sols irrigués par les eaux usées versées dans L'OUED MERZEG (CASABLANCA-MAROC). European Scientific Journal, 10, 121 138.

[16] Lokeshwari, H. and Chandrappa, G.T. (2006) Impact of Heavy Metal Contamination of Bellandur Lake on Soil and Cultivated Vegetation. Current Science, 91, 622-627.

[17] Majolagbe, A.O., Yusuf, K.A. and Duru, A.E. (2014) Trace Metals Characterisation in Environmental Media: A Case Study of Cement Production Area, Ewekoro, Southwest, Nigeria. European Scientific Journal, 3, 83-89.

https://doi.org/10.11648/j.ajep.20140302.17

[18] Tankari, D.-B.A., Guéro, Y., Dan Lamso, N., Baragé, M., Balla, A., Sterckeman, T., Ech Evarria, G. and Feidt, C. (2013) Évaluation des niveaux de contamination en éléments traces métalliques de laitue et de chou cultivés dans la vallée de Gounti Yena à Niamey, Niger. Journal of Applied Biosciences, 67, 5326-5335. https://doi.org/10.4314/jab.v67i0.95056

[19] Rapheal, O. and Adebayo, K.S. (2011) Assessment of Trace Heavy Metal Contaminations of Some Selected Vegetables Irrigated with Water from River Benue within Makurdi Metropolis, Benue State, Nigeria. Advances in Applied Science Research, 2, 590-601. http://www.pelagiaresearchlibrary.com

[20] Bambara, L.T. (2016) Etude de la Pollution en métaux lourds dans les zones de maraîchage au Burkina Faso: Cas de Ouagadougou et de Loumbila. Thèse unique de Doctorat, Université Ouaga I Professeur Joseph KI-ZERBO, p 190.

[21] Bambara, L.T., Kabore, K., Derra, M., Zoungrana, M., Zougmoré, F. and Cisse, O. 
(2015) Assessment of Heavy Metals in Irrigation Water and Vegetables in Selected Farms at Loumbila and Paspanga, Burkina Faso. IOSR Journal of Environmental Science, Toxicology and Food Technology, 9, 99-103. http://www.iosrjournals.org

[22] Prosper, D. (2007) Renforcement des capacités des exploitants maraîchers: Cas du village de Noungou dans le département de Loumbila, mémoire présente à Institut International d'ingénierie en Eau et Environnement, 124.

[23] Moumouni, D. (2011) Analyse du processus d'absorption et détection des métaux lourds. mémoire de DEA, Université de Ouagadougou.

[24] Ramteke, S., Sahu, B., Dahariya, N., Patel, K., Blazhev, B. and Matini, L. (2016) Heavy Metal Contamination of Vegetables. Journal of Environmental Protection, 7, 996-1004. https://doi.org/10.4236/jep.2016.77088

[25] Alipour, H. and Banagar, Gh.R. (2018) Health Risk Assessment of Selected Heavy Metals in Some Edible Fishes from Gorgan Bay, Iran. Iranian Journal of Fisheries Sciences, 17, 21-34.

[26] Gebeyehu, H.R. and Bayissa, L.D. (2020) Levels of Heavy Metals in Soil and Vegetables and Associated Health Risks in Mojo Area, Ethiopia. PLoS ONE, 15, Article ID: e0227883. https://doi.org/10.1371/journal.pone.0227883

[27] Miranzadeh Mahabadi, H., Ramroudi, M., Asgharipour, M.R., Rahmani, H.R. and Afyuni, M. (2020) Assessment of Heavy Metals Contamination and the Risk of Target Hazard Quotient in Some Vegetables in Isfahan. Pollution, 6, 69-78.

https://jpoll.ut.ac.ir

[28] Khan, S., Aijun, L., Zhang, S., Hu, Q. and Zhu, Y.G. (2008). Accumulation of Polycyclic Aromatic Hydrocarbons and Heavy Metals in Lettuce Grown in the Soils Contaminated with Long-Term Wastewater Irrigation. Journal of Hazard Materials, 152, 506-515. https://doi.org/10.1016/j.jhazmat.2007.07.014

[29] Moumouni, D., Cisse, O.I., Bambara, L.T., Kabore, K. and Zougmor, F. (2018) Assessment of Heavy Metals Pollution in Water and Lettuce Samples at Ouagadougou and Its Suburban, Burkina Faso. Asian Journal of Science and Technology, 9, 72587262 .

[30] USEPA (2010) Integrated Risk Information System (IRIS). United States Environmental Protection.

https://cfpub.epa.gov/ncea/iris/iris documents/documents/subst/0028 summary.pdf 